\title{
実態調査に基づく可燃物量とその表面積の分析 SURVEY AND ANALYSIS ON SURFACE AREA OF FIRE LOAD
}

\author{
油野健志*, 山仲秀利**, 大宮喜文***, 高橋 清**** \\ 田中哮義*****, 若松孝旺****** \\ Kenji ABURANO, Hidetoshi YAMANAKA, Yoshihumi OHMIYA, \\ Kiyoshi TAKAHASHI, Takeyoshi TANAKA and Takao WAKAMATSU
}

Fire spread to upper floor is mostly incurred by external window flames, which depends on the generation rate of fuel volatiles from combustible products in the fire room. The generation rate of the volatiles is thought to be strongly influenced by the area of the combustible exposed to the fire environment. In order to assess the risk of fire spread to upper floor in high-rise buildings, it is important to know the surface area of combustibles contained in building spaces in actual use. Therefore, the fire loads and surface areas of the combustibles in office, hotel room, and apartment, which are considered to be dominant use of high-rise buildings, are investigated. The correlation between the fire load density and the surface area factor, of live fire load in actual use, was obtained for each of the occupancies.

Keyword: Fire Risk, FireLoad, Surface Area, Investigation 火災危険度, 可然物量, 表面積, 調査

\section{1.はじめに}

高層建築物において噴出火炎による上階延焼の危険を 評価するためには、火災室内での熱分解ガスの発生量を 予測することができる火災性状予測モデルの開発が必要 とされる。このモデルの入力条件の中で、予測結果に大 きな影響を及ほし、かつ不確定要素の大きいものの1つ が、火災室内の収納可燃物の条件である。

火災室の開口部からの噴出火炎の長さは、火災室内で の可燃物の熱分解速度に関係しているが、この熱分解速 度は、火災時に区画内ガスからの伝熱に曝される可然物 の総表面積に依存すると考えられる。火災室内の可燃物 の量は、その空間の用途や使用目的に依存し、単位可燃 物量当たりの表面積は、可燃物の種類や、収納形態によ るであろうと考えられる。

可燃物量については、過去の調査により推奖值が提案 されているがり、建物用途によっては、調査当時と今日
において可燃物の量や材質などが変化したものもあると 予想される。また、可燃物の表面積の算定方法は、 Harmathyにより提示されているが21、これは単独の家具 等の重量と表面積の関係について当てはまると考えら れ、家具等が壁に接して置かれていたり、書類等が積み 上げられていたりする実際的な使用状況における可然物 の収納状態を考慮した時の火炎に露出される面としての 妥当性は不明瞭なままである。

そこで本研究では、実際的な使用状況での可燃物量お よび可燃物の表面積を評価することを目的として、高層 建築物の主な用途である「事務所」「ホテル」「共同住宅」に ついて改めて可燃物量の追加調査を行い、可燃物の分布 状況や、その表面積について分析した。
* 東京理科大学大学院理工学研究科建築学 専攻

***侏竹中工務店 工修

*** 東京理科大学大学院理工学研究科建築学 専攻 工修

**** 䧧安宅防災設計

***** 建設省建築研究所防煙研究室 室長 · 工博

******* 東京理科大学理工学部建築学科 教授. 工博
Guraduate Student, Dept. of Architecture, Faculty of Sci. and Eng. Science Univ. of Tokyo

Takenaka Corp., M. Eng.

Guraduate Student, Dept. of Architecture, Faculty of Sci. and Eng. Science Univ. of Tokyo, M. Eng.

Ataka fire safety design office

Head, Smoke Contorol Div., Building Research Institute, Ministry of Construction, Dr. Eng.

Prof., Dept. of Architecture, Faculty of Sci. and Eng., Science Univ. of Tokyo, Dr. Eng. 


\section{2. 可燃物の算定方法}

調査結果をまとめる際、本研究において可然物量、そ の換算值、および表面積係数 Фは既往の方法"1に基づ き、以下のように定義し算定している。

\section{1 火炎荷重の算定方法}

可然物の種類や収納状態を考慮しない単位床面積当た りの可燃物量 (実測值)を、本研究では可燃物密度とし、 式(1)で求める。

$$
\begin{array}{cl}
q=\frac{\Sigma G_{i}}{A} & \\
\mathrm{q} & : \text { 可燃物密度 }\left(\mathrm{kg} / \mathrm{m}^{2}\right) \\
\mathrm{G}_{\mathrm{i}} & : \text { 可燃物の重量 }(\mathrm{kg}) \\
\mathrm{A} & : \text { 火災区画の床面積 }\left(\mathrm{m}^{2}\right)
\end{array}
$$

また、可燃物の重量は、材質により発熱量が異なるた め、同発熱量の木材重量に換算される。これを等価可燃 物量といい、単位床面積当たりの等価可燃物量を火災荷 重というり。本研究では火災荷重を等価可燃物密度と し、式(2)で求める。

$$
q_{o}=\frac{\Sigma\left(G_{i} \cdot H_{i}\right)}{H_{o} \cdot A}=\frac{\Sigma Q_{i}}{H_{o} \cdot A}
$$

$\mathrm{q}_{\mathrm{v}} \quad$ : 等価可燃物密度 $\left(\mathrm{kg} / \mathrm{m}^{2}\right)$

$\mathrm{H}_{\mathrm{v}} \quad$ : 木材の単位発熱量 $(\mathrm{kJ} / \mathrm{kg})$

$\mathrm{H}_{\mathrm{i}}$ : 可燃物の単位発熱量 $(\mathrm{kJ} / \mathrm{kg})$

$\Sigma Q_{i}$ : 火災区画内可燃物の淞発熱量 $(\mathrm{kJ})$
本研究では、合成高分子系可燃物の単位発熱量を木材 の 2 倍、その他の書類、書籍、木製家具類などは木材と 同じとした1。

さらに、実火災時の可燃物の発熱性状は、その材質の 種類だけでなく、形状、収納形態などによっても異なっ てくる。このことを考慮した可燃物密度を本研究では換 算可然物密度といい、式(3)で求める。

$$
\begin{aligned}
& q_{o}^{\prime}= \frac{\Sigma\left(a_{i} \cdot G_{i} \cdot H_{i}\right)}{H_{o} \cdot A} \\
& \mathrm{q}_{o}^{\prime}: \text { 換算可燃物密度 }\left(\mathrm{kg} / \mathrm{m}^{2}\right) \\
& a_{i} \quad: \text { 可燃物の収納形態などにより決まる倸数 }
\end{aligned}
$$

本研究では、既往の方法”にならい、係数を次のよう にとる。

$$
\begin{array}{ll}
\text { ・スチール製家具(スチール製戸付)に収納 } & : 0.4 \\
\text { ・スチール製家具(ガラス製戸付)に収納 } & : 0.5 \\
\text { ·スチール製家具(戸なし)に収納 } & : 0.6
\end{array}
$$

\section{2 可燃物の表面稜の算定方法}

通常の収納可然物の重量と表面積の関倸は、Harmathy により式(4)のように提案されている。。

$$
A_{f}=\Phi G
$$

$$
\begin{array}{ll}
\mathrm{A}_{\mathrm{f}} & : \text { 可燃物の表面積 }\left(\mathrm{m}^{2}\right) \\
\mathrm{G} & : \text { 可燃物の総重量 }(\mathrm{kg}) \\
\Phi & : \text { 可燃物の表面樍係数 }\left(\mathrm{m}^{2} / \mathrm{kg}\right)
\end{array}
$$

なお、Hamathyによれば、通常の収納可然物の表面䅡 係数 $\Phi$ は $0.12<\Phi<0.18$ とされている。

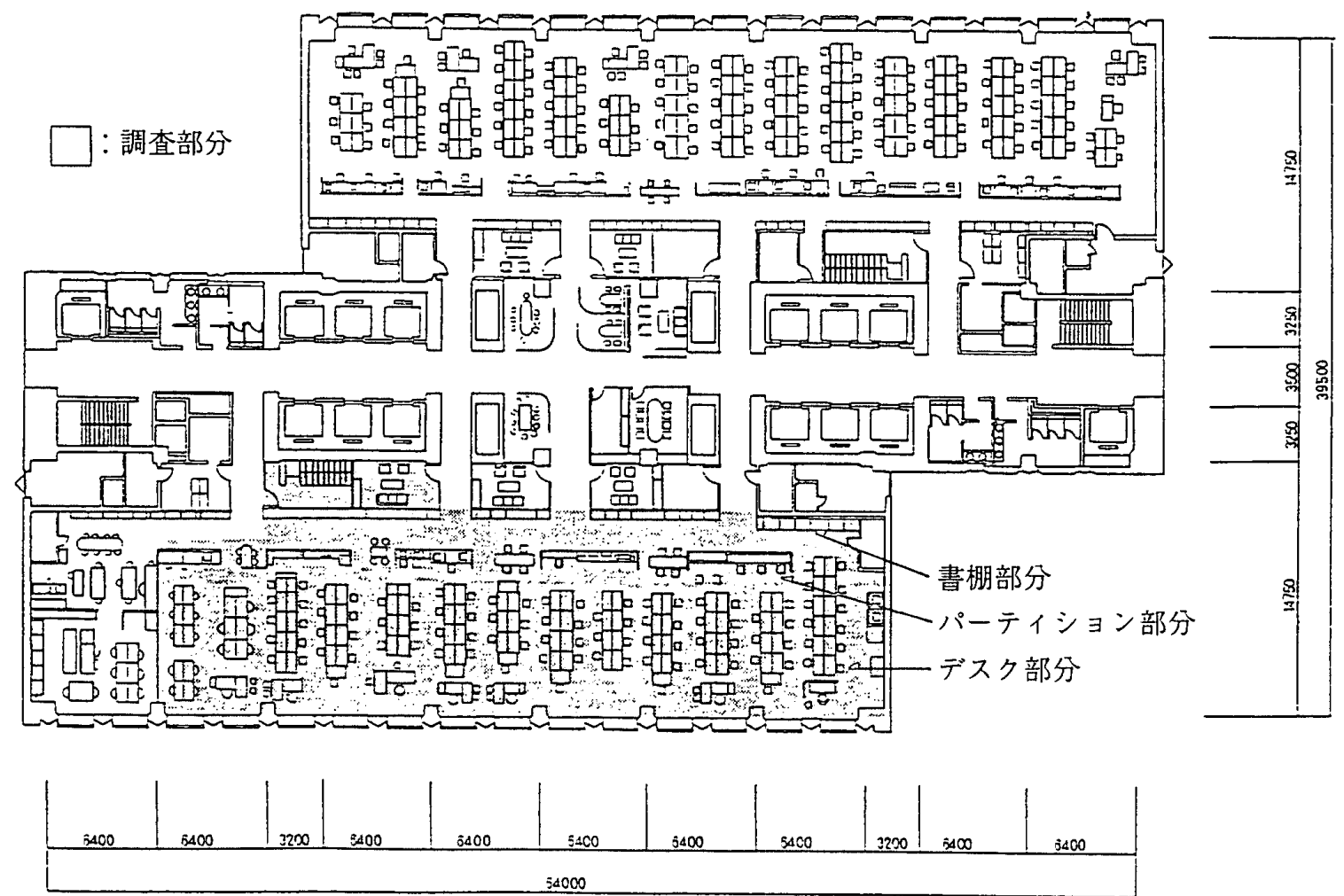

図1調㚗部分レイアウト図(一例) 


\section{3. 事務所の可燃物調査}

火災荷重、可燃物の表面積(露出面積)の火災性状への 影響を考え、以下の項目に重点を置いて、2 社の事務所 ビルについて実態調查を行った。

(1)室の用途・大きさ

(2) 家具類の材質 $\cdot$ 寸法・重量 ・配置

(3)家具内収納可燃物の材質・寸法・重量

(4) 家具類上部、床上の物品の材質・寸法・重量

(5) 可燃物の露出状態

\section{1 調查対象}

事務所では、既往の調査結果1)が幾つか存在するが、 現在はOA化やパーティションの使用の増加により、執 務空間の可燃物の変化が予想される。そこで、事務所用 途において代表的な事務室、会議室などを数例を選び、 表にによとめた部分について調查した。また、図1では調 查部分のレイアウト図の一例として、A社 $5 \mathrm{~F} の$ 平面図を 示している。

\section{表1 建物調查部分 (事務所)}

\begin{tabular}{|c|c|c|c|c|c|}
\hline 調整建物 & 㫟数 & 調査部分 & 調查趣物 & 煊数 & 調查部分 \\
\hline \multirow{7}{*}{ At杜 } & $3 \mathrm{~F}$ & 大木-n & \multirow{7}{*}{ B杜 } & \multirow[t]{2}{*}{$8 \mathrm{~F}$} & \multirow{2}{*}{ 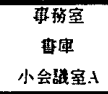 } \\
\hline & $4 \mathrm{~F}$ & 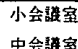 & & & \\
\hline & \multirow[t]{3}{*}{$5 \mathrm{~F}$} & 事技室 & & \multirow[t]{2}{*}{$12 \mathrm{~F}$} & 小会咾塞B \\
\hline & & 它接室 & & & 中会战室A \\
\hline & & 盘庫 & & \multirow[t]{2}{*}{$13 \mathrm{~F}$} & 中会請室B \\
\hline & $11 F$ & 食堂 & & & 大会諤室 \\
\hline & $13 F$ & OA教室 & & $1+F$ & 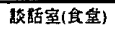 \\
\hline
\end{tabular}

\subsection{1 計測方法}

家具類や物品などの重量については、パーソナル台秤 (秤量 $150 \mathrm{~kg}$ 、感度 $50 \mathrm{~g}$ )、ヘルスメーター(秤量 $100 \mathrm{~kg}$ 、感 度500g）を各 1 台、寸法はスチール製巻尺を用いて実測 した。その際、重量測定が困難なものは家具のメーカー や型式をもとにカタログなどにより補足調査を行った。

\section{1 .2 算出方法}

事務室は、デスク部分、パーティション部分、書棚部 分(図1参照)の3つに大別し、各々について調查した。

(1)デスク部分

デスク部分では、管理職席について 2〜3席、一般 職席については対向式の、ある1ブロック 10 席各々 について寸法、重量、材質を実測した。その際、机上 の書類、OA機器、机周辺の床上に置かれている物品の 配置についてはレイアウト図(図2)と、これに対応した 調査シート(表2)を作成した。このレイアウト、および シートに記入された寸法表面積を算出した。これによ り、まずデスク 1 つ当たりの可燃物量、表面積の平均 を求めた上で、調査範囲全ての机の個数を乗じて、総 可燃物量および総表面積を算出する。
(2)パーティション部分

パーティション部分は、周囲にある可燃物に、コン ピューター類、コピー機、スチールラックなどの特徵 があるため、その特徵が異なる部分について調査を 行った。そして、デスク部分と同様実測から、レイア ウト図、調查シートを作成し、これより単位長さ当た りの可燃物量および表面積を求めた。また、特徽の類 似した部分については、その長さを乗じることで、そ の部分の総可燃物量および総表面積を算出する。この 際、コピー機など重量測定が不可能な大型機器類につ いては、測定可能な小型機より比重を求め、体積を乗 じて重量を算出している。

(3)書棚部分

書棚部分は、各種書棚 1 つ当たりの収納容量と収納 物の重量を実測し、写真などを参考に書棚の個数を乗 じて総可燃物量を算出する。また、表面積について は、露出部分のみとし、スチール製家具に密閉された ものを除いて算出する。

その他の用途の室 (書庫、応接室、会議室、食堂など) についても、代表的な家具について同様の方法を用い て、総可燃物量、総表面積を算出する。

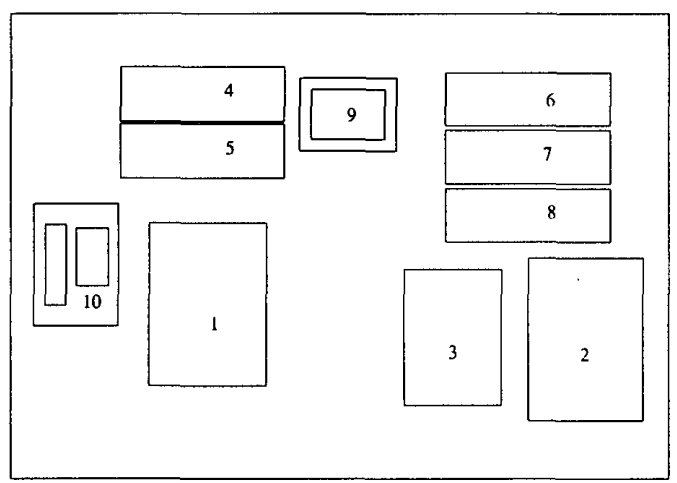

図2＼cjkstart事務所・デスクレイアウト図(一例)

表2 事務所・デスク調查シート(一例)

\begin{tabular}{|c|c|c|c|c|c|c|}
\hline 再号 & 品目名 & 材贺 & 艆( & 槽 $(\mathrm{cm})$ & 高点( $(\mathrm{N})$ & II 盟 $(\mathrm{k} ;)$ \\
\hline 1 & 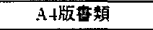 & 䖽 & 30 & 21 & 5 & 4.3 \\
\hline 2 & 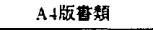 & 梏 & 30 & 21 & 3 & 3.2 \\
\hline 3 & B55版春斯 & 耗 & 26 & 18 & 6 & 4.0 \\
\hline 4 & フナイルボックス & 梅 & 30 & 10 & 21 & $2 . \overline{5}$ \\
\hline 5 & フフイルボックス & 柢 & 30 & 10 & 21 & 3.0 \\
\hline 6 & フフイルポックス & 柢 & 30 & 10 & 21 & 1.6 \\
\hline 7 & フォイルポックス & 相 & 30 & 10) & 21 & $0 . \overline{5}$ \\
\hline 8 & ファイルボックス & 梏 & 30 & 10 & 21 & +5 \\
\hline 9 & スタンプスれ & 木 & 14 & 10 & 8 & 0.4 \\
\hline 10 & 毫話 & ブラスチック & 23 & 17 & 4 & 0.4 \\
\hline
\end{tabular}

\section{2 調査結果}

\subsection{1 可燃物密度}

表3に、事務所の各室用途の可燃物密度、および等価 可燃物密度、換算可燃物密度を示している。 


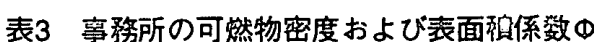

\begin{tabular}{|c|c|c|c|c|c|c|}
\hline 建物用选 & 室用迸 & 对象 & $\begin{array}{c}\text { 可燎物密度 } \\
\left(\mathrm{kg} / \mathrm{m}^{*}\right)\end{array}$ & 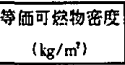 & $\begin{array}{c}\text { 喚年可短物密度 } \\
\left(\mathrm{kg} / \mathrm{m}^{2}\right)\end{array}$ & $\begin{array}{c}\phi \\
\left(m^{\prime} / \mathrm{kg}\right)\end{array}$ \\
\hline \multirow{12}{*}{ 斯政昕 } & \multirow{2}{*}{ 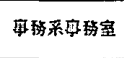 } & A 社 & 32.1 & 35.8 & 20.9 & 0.04 \\
\hline & & B社 & 28.9 & 32.9 & 16.5 & 0.03 \\
\hline & 挂街采享称室 & 迅去の町查 & 34.6 & $3 \overline{5} .6$ & 22.3 & \\
\hline & \multirow{3}{*}{ 会謑害·庀接室 } & A社 & 6.6 & 6.9 & 6.9 & 0.18 \\
\hline & & B杜 & 6.8 & 7.5 & 7.5 & 0.17 \\
\hline & & 邀去の臫查 & 6.9 & 7.8 & 7.0 & \\
\hline & \multirow{3}{*}{$5 \%$} & $A \notin \pm$ & 226.0 & 226.0 & 226.0 & 0.02 \\
\hline & & B社 & 157.3 & 157.3 & 157.3 & 0.02 \\
\hline & & 週去の䁒望 & 114.4 & 115.5 & 83.1 & \\
\hline & \multirow{2}{*}{ 4됴 } & $\mathrm{A} \neq \mathrm{E}$ & 3.1 & 3.6 & 3.6 & 0.22 \\
\hline & & B杜 & 3.0 & 3.5 & 3.5 & 0.23 \\
\hline & OA 数空 & A杜 & 7.4 & 11.8 & 11.8 & 0.12 \\
\hline
\end{tabular}

表4 亭務室の部分別の可䓡物密度および衰面獱

\begin{tabular}{|c|c|c|c|c|}
\hline \multicolumn{2}{|l|}{ 对潒家具 } & \multirow{2}{*}{ 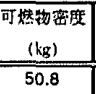 } & \multirow{2}{*}{ 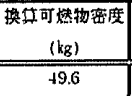 } & \multirow{2}{*}{ 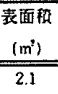 } \\
\hline \multirow{3}{*}{ 垁称デスク1つ当たり } & 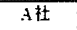 & & & \\
\hline & B杜 & 67.9 & 31.6 & 2.3 \\
\hline & 平均 & 59.4 & 40.6 & 2.2 \\
\hline \multirow{2}{*}{ 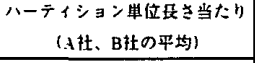 } & $\mathrm{OA}$ 部分 & 53.9 & 82.1 & +.2 \\
\hline & コピー攵 & 65.0 & 91.1 & +3 \\
\hline \multirow{3}{*}{ 収朝现単(位面和当たり } & At社 & 95.0 & 38.0 & 1.3 \\
\hline & B柱 & 45.4 & 18.2 & 1.0 \\
\hline & 平均 & 55.0 & 22.0 & 1.1 \\
\hline す里単位面和当たり & B社 & 65.5 & & 1.5 \\
\hline
\end{tabular}

(1)事務室

事務室の可燃物密度はA社で $32.1 \mathrm{~kg} / \mathrm{m}^{2} 、 \mathrm{~B}$ 社で $28.9 \mathrm{~kg} /$ $\mathrm{m}^{2}$ となった。ともに過去の技術系事務室の値 $34.6 \mathrm{~kg} / \mathrm{m}^{2}$ よりやや小さい值ではあったが、ほほ同様の值と考え られる。また、事務机や椅子などが合成高分子系可燃 物であったため、等価可然物密度は幾分增幅している が、可燃物の多くがスチール製のキャビネット・書棚 に収納されていたため、換算可燃物密度はA社で $20.9 \mathrm{~kg} /$ $\mathrm{m}^{2} 、 \mathrm{~B}$ 社で $16.5 \mathrm{~kg} / \mathrm{m}^{2}$ とかなり低減されている。

(2)会議室・応接室

会議室・応接室においては、可燃物が一部の木製家 具を除いてソファー、テーブル、椅子などで、数量も 限定されていたことから、可燃物密度はA社で $6.6 \mathrm{~kg} /$ $\mathrm{m}^{2} 、 \mathrm{~B}$ 社で7.5 $\mathrm{kg} / \mathrm{m}^{2}$ (ともに平均値) と小さかった。ま た、過去の調查結果とも大差はない。

(3)書庫

書庫における可燃物密度はA社で $226.0 \mathrm{~kg} / \mathrm{m}^{2} 、 \mathrm{~B}$ 社で は $157.3 \mathrm{~kg} / \mathrm{m}^{2}$ となり、2社とも他の室用途よりかなり大 きな值となったが、これは、室全体に書頑などの紙類 が満載されていたためで、また、フルオープンのス チールラックに収納されていたことから、換算可燃物 密度に差は見られなかった。但し、両社とも過去の値 と比較すると、1.5 2倍程度の大きな值をとっている。

(4)食堂

食堂では、可然物のほとんどがスチール製の脚の テーブル、椅子に限定されていたことから、他の用途 の室に比べ、可燃物密度はA社で $3.1 \mathrm{~kg} / \mathrm{m}^{2} 、 B$ 社で $3.0 \mathrm{~kg} /$ $\mathrm{m}^{2}$ とかなり小さい值となった。

(5) OA教室

$\mathrm{OA}$ 教室の可燃物密度は $7.4 \mathrm{~kg} / \mathrm{m}^{2}$ と比較的小さかった が、OA機器などの高分子系可然物が大半を占めていた ため、等価可燃物密度は $11.8 \mathrm{~kg} / \mathrm{m}^{2}$ と幾分大きくなっ た。

表4には調查部分の家具の種類別に可燃物密度、換算 可燃物密度および表面積を示しているが、事務所用途の ような室では、収容人数によって家具の数などが決まる ことから、可燃物量を床面積からではなく収容人数から 算定する場合の目安になると考えられる。

\subsection{2 表面䅡}

表3に示す可燃物の表面積係数 $\Phi$ は、 2 社の事務室の 值が0.04、0.03とほぼ同じであった。ここで、2 社の可 燃物密度が平均的な事務所の值といえれば、本調査の $\Phi$ は1つの目安と考えられる。また、Harmathyの値と比べ て、事務室、書庫ではかなり小さな值となり、会議室、 食堂では $0.18 〜 0.23$ と Harmathyの值より大きくなった。

表面積係数 $\Phi$ の值は、一般に可燃物密度が大きいもの ほど小さくなる傾向が見られる。これは、会議室、食堂 は、可燃物密度が少ないものの、その露出面積が大き く、逆に、事務所、書庫は可燃物密度が多いが、その多 くがスチール製の家具などに収納されていることから露 出面積が小さくなっているためであると考えられる。ま た、図3は可燃物密度に対する表面積係数 $\Phi$ の関倸を示 しており、その回帰直線は次式(5)となる。

$$
\Phi=0.54 \times q^{-10.65}
$$

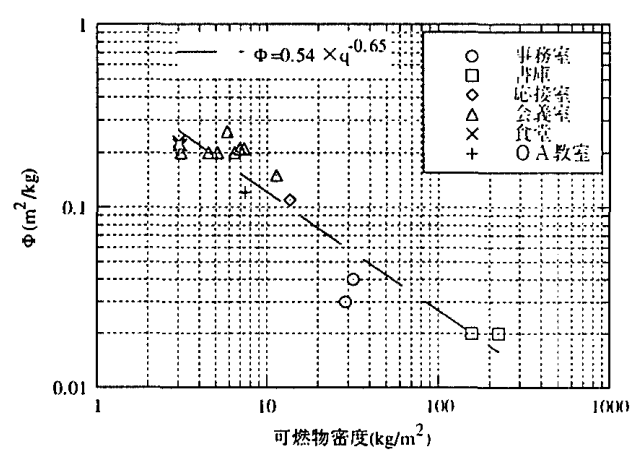

図3 表面䅡係数 $\Phi($ 事務所)

\section{4.ホテルの可撚物調㚗}

\section{1 調蒙対象}

ホテルについては、建物内に収納されている家具の種 類や数量が限定されていることから、さほど大きな経年 変化はないと考えられる。そこで、過去の実態調査" 中の可燃物量に関する資料を参考に、表5にまとめた部 分について文献調査を行った。 
表5 建物調査部分 (ホテル)

\begin{tabular}{|c|c|c|c|}
\hline 院数 & 间查部分 & 䧄数 & 㗅查部分 \\
\hline \multirow{3}{*}{$2 F$} & 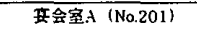 & $13 \mathrm{~F}$ & 客宝H (No.1361) \\
\hline & 共会望B (No.202、203) & $16 \mathrm{~F}$ & 客室8 (No.1622) \\
\hline & 其会宝C (No.302-305) & \multirow[t]{2}{*}{$20 \mathrm{~F}$} & 客案1 (№.2010) \\
\hline $3 \mathrm{~F}$ & ロヒー & & 客窒F (No.2017) \\
\hline \multirow[b]{2}{*}{$12 \mathrm{~F}$} & \multirow{2}{*}{$\begin{array}{l}\text { 客室A (No.1204) } \\
\text { 客室C (No.1220) } \\
\text { 客窒D (No.1227) } \\
\text { 客室E (No.1231) }\end{array}$} & $21 F$ & 客宝G (No.2120) \\
\hline & & $22 \mathrm{~F}$ & 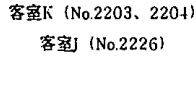 \\
\hline
\end{tabular}

\subsection{1 計測方法}

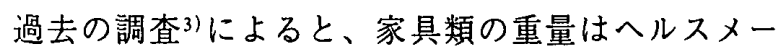
ター(秤量 $150 \mathrm{~kg}$ 、感度 $50 \mathrm{~g}$ )を1〜4台、寸法はスチール製 巻尺を用いて測定している。また、固定された家具や大 型の家具類の重量については、各々の容積に比重を乗じ て算出している。

\subsection{2 算出方法}

可燃物密度は過去の調査資料》を用いたが、この資料 中に表面積に関するデータがなかったので、各室の平面 図(図4)、それに対応した調査シート(表6)、および写真 から家具類などの配置を考慮し表面積を算出した。ここ で、各家具の寸法は調查シートに記載されているものを 使用し、詳細部分を除いて推定による算出はない。

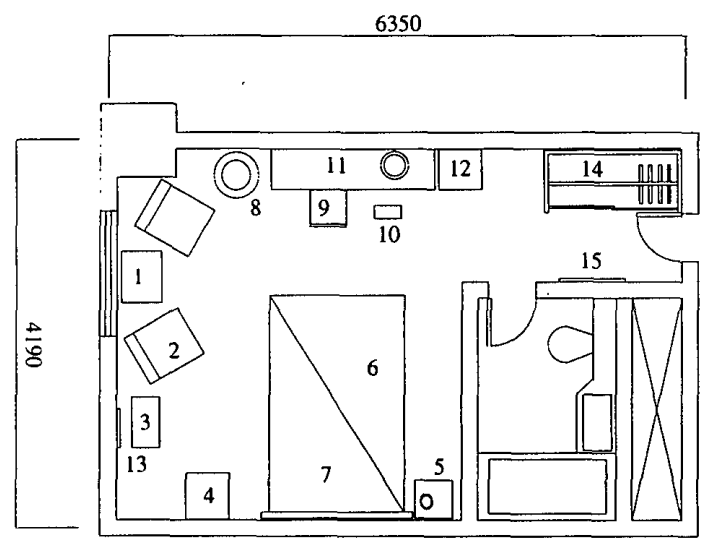

図4 ホテル・客室A平面図(一例 $)^{3)}$

表6 ホテル・客室A調査シート(一例 $)^{3)}$

\begin{tabular}{|c|c|c|c|c|c|c|}
\hline 雷号 & 品目名 & 村等 & 政(m) & 横( $(m)$ & 高き(m) & 重船( \\
\hline 1 & 机 & 木 & 0.55 & 0.55 & 0.5 & $\overline{13}$ \\
\hline 2 & 梅子 & 木、布 & 0.65 & 0.65 & 0.75 & 13 \\
\hline 3 & テレヒ⿺ & スチール、木 & 0.38 & 0.57 & 0.9 & 17 \\
\hline 4 & サイドーール & スチール、木 & $0 .+5$ & 0.45 & 0.6 & 16 \\
\hline$\overline{5}$ & +イドテーフル & 木 & 0.45 & 0.45 & 0.6 & 12 \\
\hline 0 & ベット & & 2 & 1.54 & 0.55 & 105 \\
\hline 7 & ペッドボード & 木 & 0.8 & 1.6 & 0.04 & 9 \\
\hline 8 & フロナースタント & スチール、末 & \multicolumn{2}{|c|}{0.5 (西膲) } & 1.7 & 4.5 \\
\hline 2 & 梅子 & 木、布 & 0.4 & 0.5 & 0.8 & +.5 \\
\hline 10 & こみ䈹 & スチール & 0.17 & 0.3 & 0.3 & 1 \\
\hline 11 & 机 & 木 & 0.48 & 1.8 & 0.7 & 43.5 \\
\hline 12 & 冾薜唓 & スチール & 0.44 & 0.48 & 0.7 & 32 \\
\hline 13 & 類 & カラス、末 & 0.51 & 0.42 & 0.02 & 1.5 \\
\hline 11 & ワードローフ & 木 & 0.71 & 1.49 & 2.1 & 36 \\
\hline 15 & 银梠 & 木 & 0.03 & 0.63 & 1.4 & 5 \\
\hline
\end{tabular}

\section{2 調查結果}

\subsection{1 可然物密度}

過去の調查資料》にによると、客室部分では、全可燃物 の約85 95\%が木製家具で占められており、高分子系可 燃物は、椅子類に使用されるビニールレザーやカーテ ン、カーペット類が主であった。また、椅子類が家具の 多くを占めている宴会室・ロビーを除けば、全可燃物量 に対する合成高分子系可燃物の割合は、ほとんどの客室 で5\%以下で、スチールのみの家具は全くなかった。

表7には、各室用途の可燃物密度、および等価可燃物 密度、換算可燃物密度を示している。

表7 ホテルの可燃物密度および表面積係数Ф

\begin{tabular}{|c|c|c|c|c|c|c|c|}
\hline \multirow[t]{2}{*}{ 起物用遂 } & \multirow[t]{2}{*}{ 空用途 } & \multicolumn{3}{|c|}{ 可燃物密度 $\left(\mathrm{kg} / \mathrm{m}^{\mathrm{g}}\right)^{3}$} & \multirow{2}{*}{ 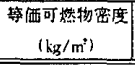 } & \multirow{2}{*}{$\begin{array}{c}\text { 換籍可燃物密見 } \\
\left(\mathrm{kg} / \mathrm{m}^{*}\right)\end{array}$} & \multirow{2}{*}{$\begin{array}{l}\Phi\left(\mathrm{m}^{2} / \mathrm{k} \cdot \mathrm{g}\right) \\
\text { |平均値| }\end{array}$} \\
\hline & & 胃团 & 平均値 & 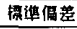 & & & \\
\hline \multirow{3}{*}{ ホテル } & 客室 & $7.8-13.3$ & 10.4 & 1.5 & 10.6 & $\overline{10.6}$ & 0.09 \\
\hline & 其会至 & $2.2-5.9$ & 3.9 & 1.5 & 4.6 & 4.6 & 0.21 \\
\hline & ロピー & & 2.7 & & 1.1 & 1.1 & 0.16 \\
\hline
\end{tabular}

(1)客室

客室の可燃物密度は7.8 $13.3 \mathrm{~kg} / \mathrm{m}^{2}$ (平均值 $10.4 \mathrm{~kg} / \mathrm{m}^{2}$ ) であった。わずかに值が分散しているのは、部屋の大 きさによって家具の数量や寸法が変わるためであると 考えられる。図5に示す客室の可燃物量の分布において は、可然物量は床面積に対してほほ比例する傾向が見 られる。また、客室内に木製家具以外の可燃物がほと んどなかったので等価可然物密度は $10.6 \mathrm{~kg} / \mathrm{m}^{2} て ゙ 、$ 実測 値との差は見られなかった。

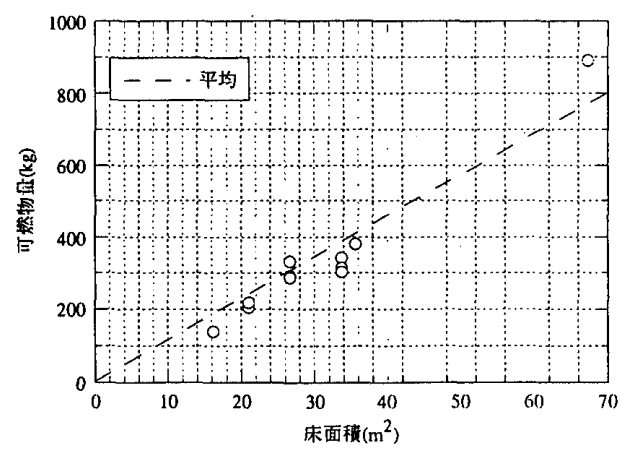

図5 客室の可然物量分布

(2)宴会室

宴会室の可燃物密度は $2.2 \sim 5.9 \mathrm{~kg} / \mathrm{m}^{2}$ (平均值 $3.9 \mathrm{~kg} / \mathrm{m}^{2}$ ) と小さいが、この值は宴会の形式や、使用人数によっ て変化すると考えられ、展示場など特別に利用する場 合は、かなり大きくなるとが予想される。しかし、そ のような場合を除けば、可然物はテーブル、椅子類な どに限定され、宴会の性質上、上記の範囲を超えるほ ど極端に多くなることも考えられない。等価可燃物密 度は $4.6 \mathrm{~kg} / \mathrm{m}^{2}$ と大きくなっているが、これは、椅子類に 
使用されているビニールレザーなど高分子系材料によ ると考えられる。

(3)ロビー

ロビーの実測は一例のみであるが、可燃物密度は $2.7 \mathrm{~kg} / \mathrm{m}^{2}$ と小さい。等価可燃物密度は $1.1 \mathrm{~kg} / \mathrm{m}^{2}$ と低減さ れたが、これは可燃物がスチール製の脚のテーブル、 椅子などであるからと考えられる。

\subsection{2 表面㺓}

表7に示す表面積係数 $\Phi$ は Harmathyの值と比べて、客 室では小さく、宴会室では大きな值となった。また、事 務所と同様、可燃物密度が大きいものほど $\Phi$ の值は小さ く、逆の場合、Фは大きくなる傾向にある。また、図6 では可燃物密度と表面積係数 $\Phi$ の回帰直線を示してお り、可燃物密度と $\Phi$ の関係は式(6)となる。

$$
\Phi=0.39 \times q^{-0.62}
$$

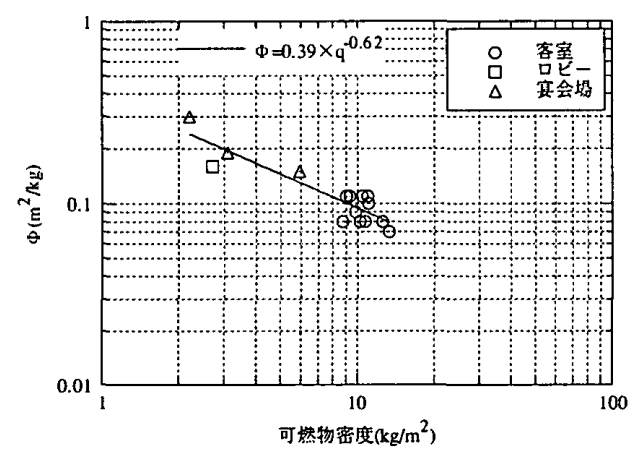

図6 表面䅡係数 Ф(ホテル)

\section{5. 共同住宅の可燃物調㸖}

共同住宅については、室内の家具や物品の材質、寸法 などを居住者の観察によるアンケート形式に基づいた過 去の調査資料4) 参考に、可燃物密度と表面積の算出を 行った。

\section{1 調㸖対畺}

この調査において、対象となる住宅へのアンケートの 配布、回収状況は表8の通りである4。

\section{表8 調宜対䱦(共同住宅)}

\begin{tabular}{|c|c|c|}
\hline 口亘対负 & 配布影 & 有知回收政 \\
\hline 社宅 & 283 & 275 \\
\hline 公团 & 1685 & 287 \\
\hline 合旪 & 1983 & 562 \\
\hline
\end{tabular}

\subsection{1 計測方法}

調査資料4)によると、家具や物品の寸法、形状につい てはアンケートに基づき、居住者が幅、奥行き、高さな どを $10 \mathrm{~cm}$ 単位程度で測定している。

\section{1 .2 算出方法}

アンケート資料 ${ }^{4}$ より、室用途を、台所、食堂、居間
(洋室 · 和室)、寝室 (洋室 - 和室)、収納室、趣味室 (洋 室・和室)に再分類した。そのデータより非復元抽出を 行い、略算式(表9) ${ }^{4)}$ を用いて、各々についての可然物量 を算出した。

また、この算出結果をもとに、調査対象全体の中から 平均的な可燃物量をもつ住戸 10 数例を抽出し、各々に ついて、平面図から家具類や物品などの配置を推定し、 居住者によってアンケートに記入されているそれらの寸 法を用いて表面積を算出した。

表9 住居の可蜘物量算定の略算式 (一例) ${ }^{4)}$

\begin{tabular}{|c|c|c|}
\hline 物品名 & 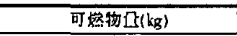 & 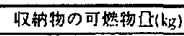 \\
\hline 洋服タンス & $\bar{M}\left(V^{*}-57.87++.27\right)$ & \multirow{3}{*}{$K \cdot 3=39$} \\
\hline 和タンス & $M(V-93.8 \cdot 2.97 \times V \geq 1)$ & \\
\hline その他 & $\mathrm{N} ;(\mathrm{V} \cdot 89.7)(\mathrm{V}<1)$ & \\
\hline 本相 & \multirow{3}{*}{ 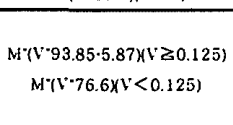 } & K. 316 \\
\hline $\begin{array}{c}\text { 代器媩 } \\
\text { サイドボート }\end{array}$ & & \\
\hline 下路植 & & 156.4 \\
\hline 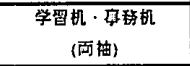 & 57.4 & 20.0 \\
\hline 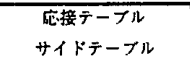 & 13.8 & \\
\hline 婴里 $(\mathrm{NAN}$ & $\mathrm{N}-5.8$ & \\
\hline 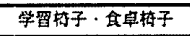 & 5.5 & \\
\hline ベゥト (シンタか & $M(152.9 \cdot 11.7)+11.7$ & \\
\hline ベッド $($ タフタ & $\mathrm{N}^{7}(89.8-22.6)+22.6$ & \\
\hline ビウたん (N年用) & $\mathrm{N}-2.85$ & \\
\hline 仙址 & $\begin{array}{c}V * 128.3+10.11(v \geq 0.15) \\
v " 111.1(v<0.15) \\
\end{array}$ & \\
\hline E゙/(フッフライイト) & 163.0 & \\
\hline \multicolumn{3}{|c|}{$\mathrm{V}$ : 体積 $\left(\mathrm{m}^{3}\right)$} \\
\hline ：収䊽 & 程度 $\begin{array}{l}\mathrm{K}=1.0 ; \text { 満 } \\
\mathrm{K}=0.75 ; 3 / \\
\mathrm{K}=0.5 ; 1 /\end{array}$ & $\begin{array}{l}\text { 杯、不明 } \\
4 \\
\text { 以下 }\end{array}$ \\
\hline M：材質 & \multicolumn{2}{|c|}{$\begin{array}{l}\mathrm{M}=1.0 \text { ；製、その他、 } \\
\mathrm{M}=0.0 \text { ；金属製 }\end{array}$} \\
\hline
\end{tabular}

\section{2 調㸗結累}

\section{2 .1 可然物密度}

この調査では、アンケート資料いをもとに各室の用途 分類、可然物密度、および表面積の算出を行ったもの で、アンケートは記入者の主観によるところが大きく、 データの一貫性について、やや疑問が残る。しかし、 デー夕数が多いことから、全般的な傾向は概ね知ること ができると考えられる。

各室用途における可燃物密度を示す表10を見ると、共 同住宅では各用途の室とも、可燃物密度は広範囲に渡っ て分散していることがわかる。また、可燃物密度の平均 值は、寝室、趣味室、収納室で $44.1 \sim 58.0 \mathrm{~kg} / \mathrm{m}^{2}$ となり、 台所、食堂、居間の值 $\left(23.0 \sim 34.9 \mathrm{~kg} / \mathrm{m}^{2}\right)$ に比べかなり大 きな值であることがわかる。さらに、可燃物量分布の一 例として、居間(洋室)での分布を示す図7からは、可燃 物量は床面積に対して、必ずしも比例の関係にあるとは 言えなかった。また、居間・度室・趣味室については 
各々和室、洋室ともに近似した值であったため、特に区 別する必要はないと思われる。しかし、趣味室は室用途 分類の際、その使用目的が明確ではなく、収納室の值と 類似していることから、趣味室を収納室と考えても差し 支えがないと思われる。このことから、共同住宅の室用 途は、台所・食堂・居間・㾛室・収納室の 5 つに大別で きると考えられる。

さらに、住居者数、住居期間、室の利用者などの要素 を含めた分析も、可燃物密度推定の有効なデー夕になる と考えられる。

表10 共同住宅の可燃物密度および表面積係数

\begin{tabular}{|c|c|c|c|c|c|}
\hline \multirow[t]{2}{*}{ 建物用透 } & \multirow[t]{2}{*}{ 室用途 } & \multicolumn{3}{|c|}{ 可撚物密度 $\left(\mathrm{kg} / \mathrm{m}^{\prime}\right)$} & \multirow{2}{*}{$\begin{array}{l}\Phi\left(\mathrm{m}^{T} / \mathrm{kg}\right) \\
\text { |平均値| }\end{array}$} \\
\hline & & 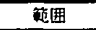 & 平均值 & 揣準倔差 & \\
\hline \multirow{12}{*}{ 共同住宅 } & 台所 $(K)$ & $0 \sim 113.1$ & 23.0 & 17.5 & 0.04 \\
\hline & 食堂(DK.LDK) & $0.9-1+9.4$ & 28.0 & 19.5 & 0.10 \\
\hline & 居間(和空) & $7.5-121.1$ & 34.9 & 25.1 & \multirow{3}{*}{0.12} \\
\hline & 居閉(洋空) & $1.5 \sim 82.6$ & 30.8 & 16.1 & \\
\hline & 居閏全体 & $1.5 \sim 121.1$ & 32.3 & 19.9 & \\
\hline & 轨妆室(洋室) & $10.5 \sim 97.7$ & 44.1 & 18.6 & \multirow{3}{*}{0.07} \\
\hline & 就旗室(和空) & $16.5 \sim 104.2$ & 46.4 & 22.7 & \\
\hline & 就然室全体 & $10.5-10+.2$ & 44.6 & 19.7 & \\
\hline & 眲味窒(洋室) & $1.0 \sim 218.9$ & 55.0 & 38.3 & \multirow{3}{*}{0.05} \\
\hline & 违味空(和窒) & . $.0 \sim 277.3$ & 58.0 & 32.4 & \\
\hline & 趣味室全体 & $1.0 \sim 277.3$ & 56.2 & 34.8 & \\
\hline & 収蚰室 & $1.0 \sim 211.1$ & 55.5 & 32.6 & 0.05 \\
\hline
\end{tabular}

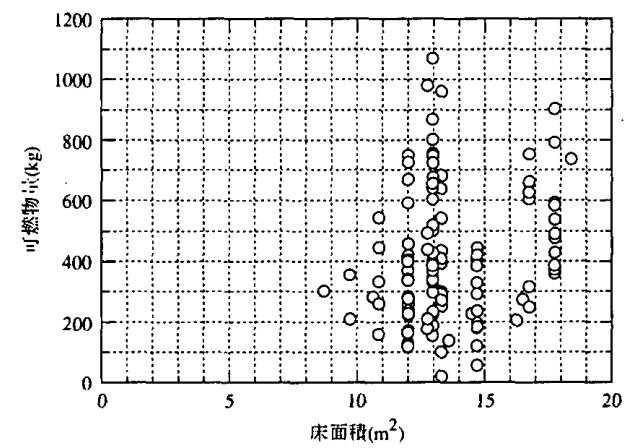

図7 居間(洋室)の可燃物量分布

\section{2 .2 表面樻}

表面積係数 Фは表10で示すように、0.04 0.12の範囲 にあり、住宅の全ての室用途でHarmathyの值より小さな 値となった。また、図8に示す可燃物密度と $\Phi$ との関係 は、事務所、ホテルと同様の傾向が見られる。これを室 用途別に回帰させると、居間は式(7)、就寝室は式(8)、 そして全室用途を区別しない場合は式(9)となる。

$$
\begin{array}{ll}
\text { 居間 } & : \Phi=6.19 \times q^{-1.11} \\
\text { 就馒室 } & : \Phi=0.77 \times q^{-0.73} \\
\text { 全室用途 } & : \Phi=0.61 \times q^{-0.64}
\end{array}
$$

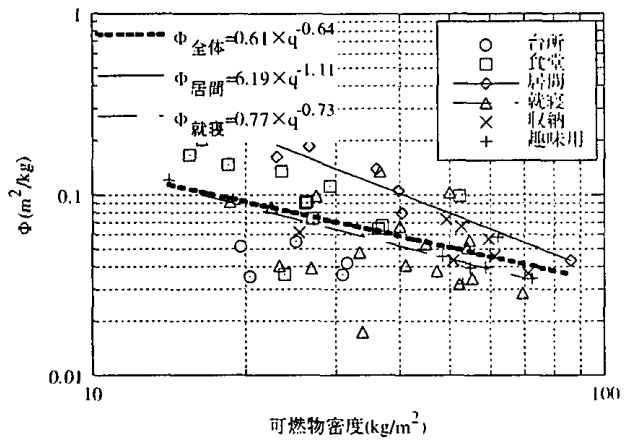

図8 表面樌係数 $\Phi($ 共同住宅)

\section{6.まとめ}

今回の調查目的である火災性状予測モデルの入力条件 として可燃物密度を用いるのであれば、対象とする建物 が、設計段階あるいは簡易に結果を得ようとする場合に おいて、表3、7、10の值を用いて可燃物量を算定するこ とは有効であると考えられる。また、3 用途の建物での 可燃物の表面積係数 $\Phi$ は、0.02 0.23となり、Harmathy

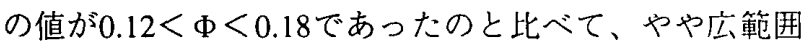
であった。

本調査の結果、可然物密度qと表面積倸数Фの関倸は

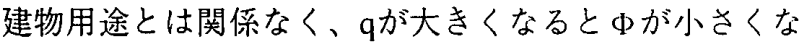
り、逆に、qが小さくなると $\Phi$ は大きくなる反比例的傾 向にあり、図9においてもそれが示されている。

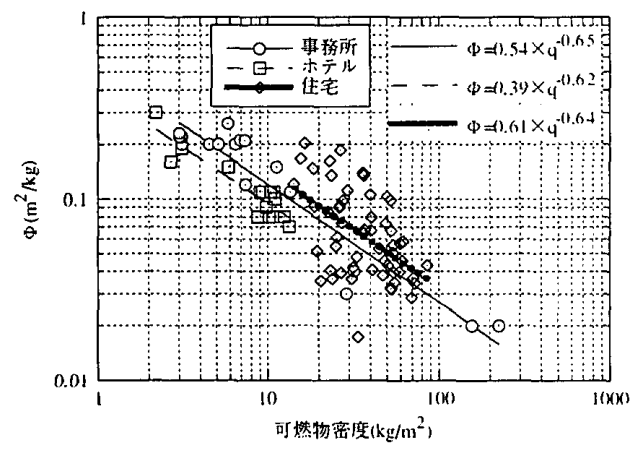

図9表面糟係数 $\Phi$ (用途別)

事務所では、室用途によって可燃物密度の值に差があ るものの、qとФの関倸を回帰させると次式(5)となる。

$$
\Phi=0.54 \times q^{-10.65}
$$

また、ホテルでは、可燃物量は床面積に比例し、qと Фの関係は式(6)に示す通りである。

$$
\Phi=0.39 \times q^{-1.62}
$$

さらに、共同住宅おいては、ホテルのように可燃物量 と床面積が比例関係を示さないが、qと $\Phi$ の関倸は次式 (9)のようになる。

$$
\Phi=0.61 \times q^{-1.64}
$$


しかし、各用途においてサンプル数などに偏りがあ ク、可燃物密度の值に差があったものの、可燃物密度と 表面積係数 $\Phi$ との関係は類似している。そこで、今後さ らに調查を行い、デー夕数を增やし、統一性をもたせて 評価する必要があるが、一応これらの式より、可燃物密

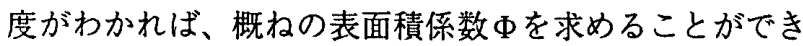
ると考えられる。

\section{『謝辞】}

本研究を行うに当たり、建設省建築研究所の萩原一郎 氏、北後明彦氏、東京理科大学学部生の遠藤利彦君、小 松明子さん(当時)の協力を得た。ここに感謝の意を表し ます。

\section{『参考文献】}

1）国土開発技術研究センター編：建築物の総合防火設計法 （第4巻 耐火設計法)，日本建築センター(1989)

2) Harmathy,TZ. : A NewLook at CompartmentFires,Part I /Part II, FireTechnology,Vol.8(1972)

3）manu都市建築研究所：建築物内の可然物量に関する実態 調査(1983)

4) 新都市型集合住宅システム開発プロジェクト(建設省委 託）: 新都市型躯体構造システム報告書, 日本建築セン 夕一-(1988)

5) 新建築学体系編集委員会：新建築学体系12, 彰国社(1983)

6）田中哮義：建築火災安全工学入門，日本建築センター (1993) 